\begin{tabular}{|l|l|l|l|l|l|l|}
\hline InterteXto & Uberaba & UFTM & v. 4 & p. 13-34 & 2011 - jul. / dez. & ISSN 1981-0601 \\
& & & n. 2 & & & \\
\hline
\end{tabular}

\title{
VOZES E ESTILOS NO SUBÚRBIO DE BONASSI
}

\section{VOICES AND STYLES IN THE SUBURB OF BONASSI}

\author{
Jorge Luís Torresan ${ }^{1}$ \\ Murilo Jardelino da Costa ${ }^{2}$
}

Resumo: nosso objetivo, nesse artigo, é discutir sobre a forma como a linguagem foi empregada na construção do romance Subúrbio, de Fernando Bonassi. Um texto em que a bivocalidade é visível, ou seja, um texto em que várias vozes introduzem estilos e discursos diferentes. Para dar conta desse objetivo, fundamentamos nossa análise na concepção dialógica da linguagem do pensador russo Mikhail Mikailovich Bakhtin (1999) e analisamos a obra à luz de sua estilística da enunciação.

Palavras-chave: Estilística da Enunciação; Dialogismo; Vozes; Estilo.

Abstract: This paper aims to discuss how the language was used in the construction of the novel Suburb, by Fernando Bonassi. A text with a noticeable bivocalization, in other words, a text in which various voices introduce different styles and discourses. In order to achieve this goal, we ground our analysis on the dialogical conception of the language of the Russian thinker Mikhail Mikailovich Bakhtin and we analyse the work in the light of his stylistic enunciation.

Keywords: Stylistics of Enunciation; Dialogism; Voices; Style.

Um leitor não muito familiarizado com uma obra cujo enredo se desenvolve a partir de temas polêmicos e violentos, que flagra o cotidiano às vezes dramático de grupos sociais que vivem às margens, na periferia, no subúrbio dos grandes centros urbanos, e trata esses dramas por meio de imagens e construções de cenas grotescas, e até mesmo escatológicas, poderá, a princípio, espantar-se. O leitor dessas obras pode ser tomado por sensações como náusea, raiva, repúdio, espanto etc. São sensações que pertencem ao cotidiano do ser humano, mas com as quais não se quer manter

\footnotetext{
${ }^{1}$ Mestre em Linguística, PUC-SP. Professor de Teorias Linguísticas na UNINOVE - SP. j-torre@uol.com.br

${ }^{2}$ Mestre em Linguística, UFPE. Professor de Teorias Linguísticas na UNINOVE - SP. murilojardelino@uninove.br
} 


\begin{tabular}{|l|l|l|l|l|l|l|}
\hline InterteXto & Uberaba & UFTM & v. 4 & p. 13-34 & 2011 - jul. / dez. & ISSN 1981-0601 \\
& & & n. 2 & & & \\
\hline
\end{tabular}

contato. Essas histórias, na verdade, refletem intimidades quase sempre não reveladas em nome da educação, da ética, da estética do formalismo. Seus heróis são figuras cujas imagens estão às avessas, ou seja, não são nada dignos de exemplos a serem seguidos, pois mostram o lado mais sórdido ou simplesmente o humano com suas imperfeições.

No entanto, o leitor também pode se pegar sorrindo com situações banais e cômicas vividas pelas personagens e se reconhecer nelas, ou mesmo contemplar momentos de pura poesia, ainda que construídos por meio de uma linguagem não poética de acordo com o cânone oficial, isto é, por meio de uma linguagem não consagrada na produção literária tradicional. Mas, sem dúvida alguma, essas obras têm seu lugar garantido no cenário literário justamente por transgredirem a linguagem, os temas, os estilos e os gêneros da tradição e por nos levarem a apreender o real sob outros pontos de vista.

A propósito dessa transgressão, especificamente a respeito da linguagem empregada nesses romances, encontramos em M. Bakhtin, autor cuja teoria suportará teoricamente essa análise, assinalado por Machado (1995), dois conceitos fundamentais que validam e justificam o estilo característico em obras cuja linguagem transgride a oficial: o conceito da literaturidade e o da bivocalidade. O primeiro deve ser compreendido como a imagem que a linguagem, pautada no padrão culto, recobre o discurso literário, linguagem reconhecida como nobre e escolhida como aquela que constituiu a tradição literária. Nesse sentido, tudo o que seja marginal à cultura oficial não deveria ser contemplado, principalmente a variante lingüística de quem está à margem. A bivocalidade diz respeito ao reconhecimento de vozes que revelam, num único enunciado, outros estilos, outros gêneros, inclusive estilos e gêneros considerados não oficiais ou os que estariam às margens dos que foram adotados na tradição literária. A junção do que chamaremos de violação do princípio da literaturidade e da presença da bivocalidade é o que norteia a linguagem que constitui o estilo encontrado, por exemplo, em Subúrbio. 


\begin{tabular}{|l|l|l|l|l|l|l|}
\hline InterteXto & Uberaba & UFTM & v. 4 & p. 13-34 & 2011 - jul. / dez. & ISSN 1981-0601 \\
& & & n. 2 & & & \\
\hline
\end{tabular}

$\mathrm{Na}$ apresentação do romance, Manoel da Costa Pinto (2006, p. 3) assinala que em Subúrbio, Bonassi apresenta

\begin{abstract}
"os índices da degradação de seres que equivalem ao lixo industrial acumulado à porta das casas ou aos utensílios engordurados de suas existências viscosas. Vem daí a estranha poesia de Subúrbio, essa escrita hipnotizada por aquilo que descreve com repulsa - ou seria melhor dizer: essa náusea transformada em literatura".
\end{abstract}

Evidentemente que, para refratar essa degradação, a linguagem empregada em Subúrbio não passou por um processo de reelaboração ou tradução da linguagem informal para a formal. O autor, por meio das vozes do narrador, das personagens, dos gêneros intercalados; representa a linguagem do contexto em que a trama se desenrola e se desenvolve com todas essas vozes ali características, fundamental para se atingir o efeito de sentido de 'uma' realidade dos fatos. Isto é, o autor reverbera e orquestra essas vozes. Assim, ele constrói o diálogo social específico de Subúrbio.

Ainda a respeito da apresentação do livro, especificamente quando o crítico se refere à transformação de náusea em literatura, ele nos indica uma questão muito cara para os estudos lingüísticos/discursivos: não há uma linguagem literária pronta, acabada, esperando pelo autor para que ele alcance seus objetivos. Para produzir esse efeito de sentido, essa sensação e essa experiência da náusea, há todo um trabalho com a linguagem, há um fazer literário esculpido em mínimos detalhes, um trabalho fotográfico com enquadramentos especiais. Trata-se de um uso específico da linguagem (de seus múltiplos recursos verbais e não verbais) para um fazer literário, assim como há um trabalho para um fazer publicitário, jornalístico, humorístico etc.

Diante do exposto, nosso objetivo é discutir sobre a forma como a linguagem foi empregada na construção de Subúrbio: um texto em que a bivocalidade é visível, ou seja, um texto em que várias vozes introduzem estilos e discursos diferentes. Para dar conta desse objetivo, fundamentamos nossa 


\begin{tabular}{|l|l|l|l|l|l|l|}
\hline InterteXto & Uberaba & UFTM & v. 4 & p. 13-34 & 2011 - jul. / dez. & ISSN 1981-0601 \\
& & & n. 2 & & & \\
\hline
\end{tabular}

análise na concepção dialógica da linguagem do pensador russo Mikhail Mikailovich Bakhtin (1999).

Não faremos uma análise exaustiva de toda a obra. Selecionamos alguns trechos que nos chamam mais a atenção. No entanto, antes da nossa análise, são necessários alguns esclarecimentos teóricos que adotamos para nortear nossa interpretação.

\section{Referencial teórico}

Considera-se aqui que não há uma linguagem especificamente literária acabada, o que existem são formas literárias de se trabalhar a linguagem, por meio de vários recursos lingüísticos, a fim de representarmos literariamente/artisticamente temas diversos, captados pela sensibilidade de alguns poetas e escritores. Esse fato pode ser exemplificado se observamos 0 desenvolvimento da produção literária, tendo em vista o contexto social da atividade de produção do romancista e a situação de enunciação narrativa, isto é, aquela a partir da qual a narrativa se desenvolve. Assim, todo discurso resulta do evento histórico, único, que é sua enunciação. Em cada um desses contextos, apreende-se como o homem interagia e interage com os mais diversos e muitas vezes repetidos temas de seu interesse como, por exemplo, o amor: sentido e descrito de várias formas pelo homem ao longo da história!

Alguns autores, filiados às duas principais correntes da estilística do século XX, a saber, a estilística linguística e a estilística literária, procuram, ao fazer a análise do romance, descrever a linguagem do autor. Para Bakhtin, contudo, a única maneira de analisar o romance estilisticamente se dá por meio da estilística do gênero.

Bakhtin concebe a enunciação a partir de um novo ponto de vista: o dialógico. A enunciação dialógica comporta algo mais que o simples ato de tomar a língua e colocá-la em funcionamento; para o pensador russo, ela dá 


\begin{tabular}{|l|l|l|l|l|l|l|}
\hline InterteXto & Uberaba & UFTM & v. 4 & p. 13-34 & 2011 - jul. / dez. & ISSN 1981-0601 \\
& & & n. 2 & & & \\
\hline
\end{tabular}

significação à língua, determinando importantes aspectos de tempo e espaço que, a cada enunciação, são únicos. O real significado de um enunciado só será compreendido pelas pessoas que interagem mediante a compreensão do contexto que as envolve. Para Bakhtin (1999, p. 154):

"A língua existe não por si mesma, mas somente em conjunção com a estrutura individual de uma enunciação concreta. É apenas através da enunciação que a língua toma contato com a comunicação, imbui-se do seu poder vital e torna-se uma realidade".

Esse pensador destaca também uma outra importante questão ligada à enunciação: a inter-ação. Sobre isso, Brait e Melo (2005, p. 68), tratam da enunciação tendo como referência a obra bakhtiniana Marxismo e Filosofia da Linguagem, e sintetizam a questão da interação em relação à enunciação da seguinte maneira:

"desta maneira, nessa obra, uma importante perspectiva de
enunciação vai sendo tecida, sempre numa dimensão
discursiva, implicada num caráter interativo, social, histórico,
cultural. Um dos méritos dessa obra é justamente ter difundido
a idéia de enunciação, de presença de sujeito e de história na
existência de um enunciado concreto, apontando para a
enunciação como sendo de natureza constitutivamente social,
histórica que, por isso, liga-se a enunciações anteriores e a
enunciações posteriores, produzindo e fazendo circular
discursos" (p. 68).

É justamente por meio desse viés teórico que compreendemos a enunciação. Sejam quais forem os objetivos dos sujeitos, ao tomar a língua e pô-la em funcionamento estarão produzindo discurso, e sempre num movimento norteado pela interação que, a propósito, ainda no arcabouço teórico bakhtiniano, nos leva a considerar a visão dialógica sobre a linguagem na medida em que numa enunciação há sempre outras que foram retomadas e que suscitarão outras tantas. O romance Subúrbio foi produto de uma interação; trata-se de um discurso, e a nossa intenção é tratar justamente dos outros discursos que o constituem. 


\begin{tabular}{|l|l|l|l|l|l|l|}
\hline InterteXto & Uberaba & UFTM & v. 4 & p. 13-34 & 2011 - jul. / dez. & ISSN 1981-0601 \\
& & & n. 2 & & & \\
\hline
\end{tabular}

\section{A concepção dialógica}

Ao nos reportarmos ao conceito de enunciação dialógica, percebemos que automaticamente nos deparamos com dois conceitos que se entrelaçam e que se complementam quando pomos a linguagem no centro das discussões, são eles a interação e o diálogo. Ainda de acordo com a citação de Brait e Melo (2005), temos: todo enunciado (produto de enunciações, portanto discursos) interage com outro(s) enunciado(s) num interminável fio dialógico, isto é, nossos discursos estão sempre atravessados e sempre atravessam outros discursos. Nas palavras de Bakhtin (1997, p. 183):

"a linguagem só vive na comunicação dialógica daqueles que a usam. É precisamente essa comunicação dialógica que constitui o verdadeiro campo da vida da linguagem. Toda a linguagem, seja qual for o seu campo de emprego (a linguagem cotidiana, a prática, a científica, a artística, etc.) está impregnada de relações dialógicas".

O dialogismo a que se refere Bakhtin perpassa e compõe toda a produção humana na medida em que os nossos posicionamentos, os nossos discursos são sempre reações/respostas a outros discursos que consequentemente causarão reações/respostas nos outros. Podemos perceber esses diálogos por meio de várias construções, desde as mais explícitas e facilmente observáveis como as trocas comunicativas entre dois sujeitos, as citações diretas ou indiretas de outros textos, portanto temos aí todas as relações intertextuais, o recurso da paródia, da ironia, o uso de aspas, as informações implícitas (os pressupostos e subentendidos), a de mescla de gêneros textuais, literários, estilísticos em uma única produção, isto tudo ocorrendo no interior de qualquer produção comunicativa e cultural nos mais diversos níveis de letramento, ou seja, desde as produções mais elitizadas até a mais populares, tanto nas formas verbais como nas não verbais. (STAM, 1992).

Uma das atividades do analista de discurso (seja qual for o discurso) é 


\begin{tabular}{|l|l|l|l|l|l|l|}
\hline InterteXto & Uberaba & UFTM & v. 4 & p. 13-34 & 2011 - jul. / dez. & ISSN 1981-0601 \\
& & & n. 2 & & & \\
\hline
\end{tabular}

sair da imanência das frases, dos seus limites fonéticos/fonológicos, morfológicos, sintáticos, para observar o que está além desses limites e assim reconhecer a trama dialógica dos discursos e os sentidos ali produzidos. A leitura e análise da obra Subúrbio aqui proposta leva em consideração o dialogismo a que se refere Bakhtin, observável por meio das vozes que conseguimos ouvir na obra e o que elas nos revelam.

\title{
As vozes em Subúrbio
}

Iniciamos nossa análise do livro Subúrbio com o que Machado (1995, p. 50) diz a respeito do romance a partir da visão bakhtiniana:

\begin{abstract}
"antes de mais nada, por ser uma abordagem que entende $o$ romance como discurso, ou seja, representação de linguagens em confronto, a teoria de Bakhtin duvida da noção de romance como representação de um único discurso elaborado pela língua culta oficial. Romance é para Bakhtin um gênero literário em prosa, constituído pela multiplicidade discursiva das línguas e das linguagens" (grifo nosso).
\end{abstract}

Considerar um romance como um gênero do discurso em que há confronto de linguagens é uma forma de se operacionalizar o conceito de funcionamento dialógico da linguagem e é exatamente essa operação que perseguimos aqui. Dar a um romance o status de discurso nos faz pensar sobre alguns pontos como, por exemplo, o fato de estar inscrito num momento histórico, enunciado a partir de sujeitos inseridos num determinado contexto socioeconômico, com seus conflitos, desejos, necessidades, tudo orquestrado pela voz do narrador, que, de certa forma, ecoa e refrata posicionamentos ideológicos na sociedade. Em Subúrbio, Bonassi cria uma história que é o reflexo de tantas outras que já ocorreram e que ainda ocorrem nos espaços urbanos com toda a sua complexidade - Bonassi transforma em literatura 0 que ocorre na realidade, portanto, as vozes que ouvimos ecoar em Subúrbio, todas interagindo de certa forma entre si, dão corpo à obra e nos faz reconhecê-la como uma quase biografia de vários cidadãos comuns e que poderíamos encontrar em outros momentos já vividos por outras personagens 


\begin{tabular}{|l|l|l|l|l|l|l|}
\hline InterteXto & Uberaba & UFTM & v. 4 & p. 13-34 & 2011 - jul. / dez. & ISSN 1981-0601 \\
& & & n. 2 & & & \\
\hline
\end{tabular}

reais.

De forma bastante resumida, em Subúrbio, vemos a crise no relacionamento de um casal já com idade avançada, cujo marido, já aposentado, se vê envolvido emocionalmente com uma menina. O fim do enredo é marcado por um ato de pedofilia, seguido por um linchamento, tendo como cenário uma região no subúrbio (periferia) da capital paulista, especificamente a rua Lombroso que

\begin{abstract}
"se encontra numa sucessão de morros baixos, mas íngremes, na continuação da serra do Mar. Tem por um lado a Vila prudente e o largo de Vila Zelinda, com a igreja, o hospício e os lituanos. Tem pelo outro a margem esquerda do Tamanduateí, lá embaixo, na divisa com São Caetano do Sul". (BONASSI, 2006, p. 13)
\end{abstract}

As personagens habitam um cenário conhecido pelos paulistanos, que dá maior verossimilhança à obra. Nesse local, vive o velho casal num "quarto, sala, cozinha e banheiro. Quando a velha não quis mais ser a mulher do velho, fez sua cama de armar e colocou no corredor. Definitivamente". (BONASSI, 2006, p. 15) O leitor perceberá durante toda a trama a presença do discurso da crise entre casais cujo relacionamento já se esgotara e, por maior conveniência, os dois não se separam e sim se suportam durante toda uma vida.

O próprio título do livro, Subúrbio, já é uma referência a esse espaço 'bivocal'. Como vimos, o cenário da trama é uma região da capital paulista com endereço certo e que, portanto, como todo subúrbio, conforme a sua definição, situa-se numa área distante da região central da cidade de São Paulo - a trama se passa no subúrbio. É muito comum a idéia de que nas áreas centrais, principalmente das grandes cidades, a infraestrutura é melhor, é o local onde fica o grande comércio, é para onde uma grande massa de trabalhadores vai todos os dias em transportes apertados, local onde as pessoas resolvem suas pendências, fazem suas compras, vão se divertir etc., enquanto que nas 


\begin{tabular}{|l|l|l|l|l|l|l|}
\hline InterteXto & Uberaba & UFTM & v. 4 & p. 13-34 & 2011 - jul. / dez. & ISSN 1981-0601 \\
& & & n. 2 & & & \\
\hline
\end{tabular}

regiões suburbanas encontramos os mais carentes, os lugares com o valor dos aluguéis mais barato, que sofrem mais com ausência de infraestrutura, portanto há uma disparidade acentuada entre as regiões suburbanas e as não suburbanas. Ao lermos, então, o título do livro, automaticamente tomamos consciência dessas desigualdades costumeiras entre o subúrbio e as outras regiões mais abastadas. Dessa forma, o leitor, logo de início, percebe que há aqui certo diálogo (mesmo que subentendido) estabelecido entre a vida que se leva na área central com a que se leva nas áreas mais retiradas. Ou seja, o título do livro nos faz ouvir essa voz daqueles que residem nos subúrbios com todos os seus problemas, sendo assim não se trata de um caso de pedofilia que ocorre, por exemplo, nos Jardins ou em qualquer outro bairro de classe média ou alta da cidade de São Paulo, o que daria à trama um outro tom, pois teríamos em cena uma outra realidade social, com outros sujeitos envolvidos, com contextos diferentes. O trecho abaixo transcrito, em que temos a descrição da casa dos velhos, dimensiona a realidade econômica das personagens e do local:

"no banheiro separado do resto da casa, o chuveiro, a privada sem tampa e as prateleiras. Duas das paredes tinham prateleiras até o teto. Cobertas com cortinas de cambraia florida, plissadas em cabos de vassoura, essas prateleiras guardavam, por exemplo, todos os sapatos já comprados pelos velhos. Também chinelos de dedo tortos e amarelecidos; coleções de cadarços almanaques e revistas; vidros de maionese Helmman's hermeticamente fechados pela ferrugem (...), Saindo do banheiro, três passos e a porta da cozinha está à direita. Uma cozinha turva. Décadas de frituras recobriram cada centímetro do lugar com uma camada impermeável e grudenta de vapor de gordura. (...) Como num tempo antes tinha acontecido um problema com a manilha que atravessava a cozinha de fora a fora, a cerâmica do chão foi quebrada. Do conserto adiado resultou uma passarela de vermelhão. A tentativa de diminuir a falta de piso destruído... Indo por essa passarela, entra-se na sala. (...) A sala, no tempo dessa história, era o lugar mais vazio da casa. Um sofá, duas poltronas e o tapete soltando pêlo. (...) Saindo da sala, um corredor. No corredor só a cama da velha. O corredor estava tão atulhado por esse móvel que a estante (com a coleção de 


\begin{tabular}{|l|l|l|l|l|l|l|}
\hline InterteXto & Uberaba & UFTM & v. 4 & p. 13-34 & 2011 - jul. / dez. & ISSN 1981-0601 \\
& & & n. 2 & & & \\
\hline
\end{tabular}

santos de gesso, a bíblia e o relógio digital) teve que ser parafusada na parede (...). O quarto tinha ficado pro velho. Depois. A luz desse quarto, abafada num globo leitoso, se acendia por um fio que vinha de um furo num canto do teto (...). No quarto, a cama do velho ocupava o centro de tudo. Agora a cama do velho. Depois. A marca dupla dos corpos resistindo à ausência da mulher. A cômoda e o guarda-roupa guardando as roupas dos dois. Não tinham mexido nisso. Desde sempre." (BONASSI, 2006, p.16)

A narração no livro também é um aspecto que merece destaque. O livro está segmentado em vários capítulos, muito pouco extensos, nos quais o narrador apresenta momentos vividos pelas personagens como se nos fossem apresentadas fotos que registrassem tais momentos. Há uma cronologia e uma estrutura bastante linear. Os fatos são narrados por meio de frases curtas; muitas, nominais, cujo objetivo provavelmente é nos fazer experimentar o tédio da vida das personagens que habitam esse espaço. Na sequência abaixo, apreende-se uma linguagem que não se preocupa com a ordem canônica da sintaxe da língua: sujeito, verbos e complementos. O fato é narrado por meio de seqüências de palavras e expressões:

“O velho. 37 anos de casa. Assim: ...descer a rua - esperar -
subir no ônibus Mercedes Benz- dormir - acordar - descer do
ônibus Mercedes Benz - entrar pela portaria - entrar pela
portaria 3 - picar o cartão - subir para o vestiário - número 56
amarelinho - abrir o armário de lata verde/cinza - despir-se da
roupa recém-posta em casa - caminhe com cuidado - não
corra - CIPA - vestir o macacão azul de peça única - duro de
suor seco graxa óleo cavaco poeira - descer para a linha de
produção - atravessar a fábrica - ferramentaria - prensas -
fundição (...) vestir a roupa de casa - vapor suor seco graxa
óleo cavaco poeira - descer para portaria 3 - picar o cartão -
sair pela portaria 3 - subir no ônibus Mercedes Benz - dormir -
ser acordado - descer do ônibus Mercedes Benz - subir a
rua... Se aposentou com 37 anos de casa. O velho.”
(BONASSI, 2006, p. 29)

Uma rotina que caracteriza a vida, o cotidiano do velho, a repetição ao longo de 37 anos, o tédio, a falta de sentido, o mesmo, o nada. Em Subúrbio, o foco principal são os fatos vividos e não necessariamente quem os vive, prova 


\begin{tabular}{|l|l|l|l|l|l|l|}
\hline InterteXto & Uberaba & UFTM & v. 4 & p. 13-34 & 2011 - jul. / dez. & ISSN 1981-0601 \\
& & & n. 2 & & & \\
\hline
\end{tabular}

disso é a forma como as personagens são tratadas, ou seja, elas não têm nome próprio; falta-Ihes uma identidade. O narrador as denomina por meio de palavras comuns que apenas as caracterizam como: o velho, a velha, a menina, o marido, a mulher, entre outros que vão compondo a trama. Os nomes próprios que aparecem no livro não fazem parte diretamente da história como, por exemplo, no momento em que a velha recebe uma carta anônima solicitando que ela dê continuidade a uma corrente da sorte. Nesta carta, nomes como: "José Eliot”, "Sauli Aulthor Cani, Constantin Diaz, Carlos Bonetin são citados, mas em nada interferem na narrativa do livro. Aqui a voz do discurso popular das simpatias, então, se faz ouvir o que também auxilia a melhor caracterização da simplicidade das personagens.

Somando-se a essa intenção de enfatizar os fatos e não quem os vive e ao cenário da trama pincelado com cores características de uma realidade social desfavorável economicamente como é costumeiro nos subúrbios dos grandes centros, temos a linguagem empregada pelo narrador que se encontra na esfera do considerado não oficial, de uma linguagem carregada de palavras que sugerem o escatológico, o baixo, aquilo que "deve" ser dito às escondidas, que não aparece, pelo menos de maneira aberta e clara, em lugares que saem do perímetro urbano composto por uma outra realidade sócio-econômica marcada pela elite com sua linguagem formal, a considerada oficial:

"Tarde. O dia deslizando. Louças. Louças quebrando. Panelas
batendo ao longe. O velho na cozinha. Sentado na cozinha. A
cabeça pendurada no pescoço. Os ladrilhos vermelhos. A
meia. As bolinhas de cobertor da meia. O cadarço. A ponta do
sapato. A poeira suspensa na ponta do sapato. Barulhos.
Barulhos mais perto, chegando. Chegaram. Ouviu a mulher
vizinha chegar. Ouviu a vizinha chegar. A vizinha
sem...Marido...Saco de merda...Ela. Do outro lado. Uma
parede. Chegou com o rastro dos seus barulhos cruzando a
casa. A chave girando no tambor. Ele a reconheceu no barulho
de sua chave. A mão dobrando a fechadura. Ele a reconheceu
cruzando a casa desde a porta da frente. Passos passaram
pelo quarto. Cruzaram. Passos se aproximaram. Pela sala. A
bolsa foi atirada sobre o sofá. O corpo vencendo a cortina de 


\begin{tabular}{|l|l|l|l|l|l|l|}
\hline InterteXto & Uberaba & UFTM & v. 4 & p. 13-34 & 2011 - jul. / dez. & ISSN 1981-0601 \\
& & & n. 2 & & & \\
\hline
\end{tabular}

tiras de plásticas. Ele soube. Até a cozinha. Reconheceu. Sandálias batendo e arrastando nas lajotas. Mexeu no armário - Na mesa. O velho ouviu. Depois ela mexeu bem atrás dele. Naquela hora. Bem ali. Uma parede, só uma parede. Atrás dele. Nada mais, atrás dele. Saiu. A mulher saiu. Ela entrou no banheiro. Depois de chegar em casa assim no meio da tarde. No horário morto da tarde morta. Ele também foi ao banheiro. Na ponta dos pés. No banheiro. Ele esperando: um, dois, três, quatro... A mulher no banheiro. No dela. No dele a espera ofegante na parede. Outra vez. Mais uma. A espera. Ela. Ela bateu a porta. A mulher bateu a porta. $O$ velho se atirou sobre o furo na parede. Outras vezes. Tirou o pedaço de sabão protetor e olhou no corpo dela... O corpo dela, chegando de tarde. O corpo da mulher chegando. O corpo - onde a mulher levou o corpo? Onde o corpo? Quem levou o corpo? -, a mulher cruzou a visão do furo, mão na nuca, mão no pescoço. Outra vez. Um varal de lençóis ondulando diante do espelho, os cabelos. No espelho o olho da mulher não estava olhando pra ele. Olhava o próprio corpo, sentava-se na privada. $O$ velho esfregando o rosto na parede. Poeira, poeira úmida. Só uma parede. A mulher. Outra vez. O corpo. O velho umedeceu a mão na poça d'água que pingava do chuveiro.Umedeceu, baixou as calças, se ensaboou com o pedacinho. Um orifício, um pedacinho. A mulher urinou na privada. $\mathrm{Na}$ sua. $\mathrm{Na}$ dela. Barulho. O barulho vigoroso da urina na privada, respingos. $O$ velho olhava, se ensaboava, pra dentro - pra fora - pra dentro, a mulher se levantava, apanhava o papel higiênico e se secava. Se secava dentro. O olho do velho no movimento da mão. A curva. A penugem úmida. Depois outro papel, e mais outro, e mais outros, a mulher jogou todos na privada. Observou o molhar, o pesar e o cair, papéis afundando na sua própria urina. $O$ velho pra dentro - pra fora - ensaboava, a mulher passava a mão. Nela. Nela mesma. A mão de novo, os cabelos pra cima e pra baixo, a mão, ensaboava, pra fora, pra dentro, a mulher com a mão, o pulso, $\mathrm{n}$ o meio das pernas, o cheiro, o cheiro vigoroso subindo até o orifício, a mão, o pulso, a vala, a vala - a valeta, pra cima - pra baixo, cabelos passando passando, a mulher, o velho...

- Vaca-vaca-vaca.

Vaca da tarde, a tarde morta, ensaboava, ele a reconheceu, o barulho da chave, pra dentro - pra fora, ele reconhecendo, em cima, embaixo, a mão, as unhas, unhar-unhar, sem nada, sem merda, sem saco de merda, sem marido...

- Puta-puta-filha-da-puta. 


\begin{tabular}{|l|l|l|l|l|l|l|}
\hline InterteXto & Uberaba & UFTM & v. 4 & p. 13-34 & 2011 - jul. / dez. & ISSN 1981-0601 \\
& & & n. 2 & & & \\
\hline
\end{tabular}

A mulher, a vizinha, a mão, o pulso lavrando, vala valeta, escorrendo, o cabelo voando, a mão, lá dentro - na frente dele! - Na minha frente! Ô puta-puta-filha-da-puta.

E ela vai, ela vai, ela jogava o corpo...

- Gira-gira-pomba-gira.

Sentada na privada na urina aguada e a mão...

- Nem se vê nem se vê!

Lavrava, melava, machucava, aprofundava, suspiravasuspirava...

- Vai-vai-vai, saiu-saiu...

Um sopro melado, o corpo jogado, um bufo, ele foi ela foi a mão pra fora pra cima pra dentro dentro fora fora ensaboava o velho pra dentro pra cima pra fora debaixo, o orifício, o buraco, o barulho, a parede e a coisa a coisa a coisa de merda ele agora a coisa reconheceu...

\section{Saiu-sai-sai!}

E saiu. Saiu dele. Lascas de muco voando, batendo e escorrendo na parede limbosa. A coisa desceu ao ralo, e sumiu". (BONASSI, 2006, p. 61)

Esse longo trecho do livro, em que o narrador mostra o interesse do velho pela vizinha, é marcado pelo estilo do grotesco, constituído por palavras, expressões e ações pertencentes à linguagem não oficial da tradição literária, à linguagem pertencente à oralidade do cotidiano, no entanto, esse grotesco é de estrema importância, pois ele ajuda a dar o tom de realismo que a obra exige. O grotesco em Subúrbio chega às formas do escatológico. Dessa forma, encontramos as vozes do estilo grotesco como uma espécie de "transgressão" do estilo culto da tradição literária, fato que também auxilia a aproximação da trama à realidade dos fatos que realmente ocorrem no nosso meio e que sabemos bem registrados com linguagens muito variadas e nem sempre com base na formalidade da língua culta, isto porque o dialogismo bakhtiniano a que nos referimos é "um fenômeno que se articula a partir da representação da voz 


\begin{tabular}{|l|l|l|l|l|l|l|}
\hline InterteXto & Uberaba & UFTM & v. 4 & p. 13-34 & 2011 - jul. / dez. & ISSN 1981-0601 \\
& & & n. 2 & & & \\
\hline
\end{tabular}

não apenas dos personagens, mas de estilos, de épocas, de grupos sociais" (MACHADO, 1995, p. 62).

Antes de dar continuidade a nossa análise, é importante que entendamos melhor o que estamos considerando como o estilo grotesco. Para Sodré e Paiva (2002, p. 62):

"a equação mais simples desta categoria estética será: Grotesco = Homem \# Animal + Riso. Daí partem as modalidades atinentes à escatologia, à teratologia, aos excessos corporais, às atitudes ridículas e, por derivação, a toda manifestação da paródia em que se produza uma tensão risível, por efeito de um rebaixamento de valores." (grifo nosso)

Para chegar a essa definição da estética do grotesco, os autores se fundamentam no comportamento e na produção de importantes autores que, de alguma forma, trataram do grotesco como um elemento integrador da cultura artística da humanidade. Os autores citam, por exemplo, Victor Hugo (séc. XIX) conhecido por questionar a estética clássica com vista aos ideais da arte moderna romântica por meio justamente da valorização de elementos que eram de exclusividade da cultura popular, portanto até então muito distantes do mundo da arte, e neste mesmo intento seguem outros nome como Hegel, Goethe, Schlegel. O que Victor Hugo quis foi:

"criticar as idealizações artísticas, mas de modo a chocar, a provocar um certo mal-estar, para que não restem dúvidas sobre uma mutação estética em andamento, pela qual a arte moderna deveria promover o enterro das formas simbólicas do passado, que ele citava como 'os tempos primitivos, os tempos antigos." (SODRÉ \& PAIVA, 2002, p. 42)

Importante destacar, de acordo com autores, que a valorização da estética do grotesco passou por um longo período de hibernação e foi a modernidade que a resgatou principalmente pela iniciativa de dois autores: Wolfgang Kayser, com a obra O Grotesco, e Mikhail Bakhtin, com A Cultura Popular na Idade Média e No Renascimento. O Contexto de François Rabelais. 


\begin{tabular}{|l|l|l|l|l|l|l|}
\hline InterteXto & Uberaba & UFTM & v. 4 & p. 13-34 & 2011 - jul. / dez. & ISSN 1981-0601 \\
& & & n. 2 & & & \\
\hline
\end{tabular}

Ambos os autores destacam a necessidade de se dar importância à presença de aspectos estéticos tidos como grosseiros, que de alguma forma não eram reconhecidos como válidos e dignos de compor trabalhados reconhecidamente artísticos. No entanto, enquanto Kayser vê no grotesco um aspecto negativo e limitador, Bakhtin nega tais aspectos, atribuindo ao grotesco um poder renovador. Nosso objetivo aqui não é tratar exaustivamente as origens e concepções do grotesco, mas sim mostrar, mesmo que de forma breve, que se trata de um aspecto que foi e ainda é importante quando o assunto é arte nas suas mais diversas formas de manifestação, inclusive na Literatura, e que está sempre presente no nosso cotidiano, pois "seja nas manifestações grosseiras do riso, seja nas mais sutis, o grotesco pode comparecer, indicando a derrocada do sentido estabelecido das coisas." (SODRÉ \& PAIVA, 2002, p. 63)

Os autores propõem, inclusive, uma classificação das formas como o grotesco pode se manifestar. São elas: a) Escatológico = situações propriamente escatológicas, caracterizadas pelos desejos humanos, pelas secreções, pelas partes baixa do corpo; b) Teratológico = manifestações risíveis diante de aberrações, monstruosidades, deformações; c) Chocante = seja por elementos escatológicos ou teratológicos, aqui a intenção é sempre cunho sensacionalista; d) Crítico $=0$ objetivo com esta categoria é promover uma discussão para que valores e ideais sejam revistos. Ainda em relação ao estilo grotesco, que vimos não ser nada gratuito, em Subúrbio podemos perceber que ele não é característico apenas nas vozes das personagens, o narrador emprega tal estilo ao conduzir a trama. Isso, para Brait (2001, p. 248), em virtude de:

"a habilidade do autor permite que ele recupere níveis distintos
de expressão não apenas para cada uma das personagens,
mas muitas vezes mesclados na mesma frase e fazendo o
próprio narrador participar de registros que se afastam da
norma culta. Essa é sem dúvida uma forma de trabalhar o
léxico e a sintaxe, englobando no mesmo espaço os
privilegiados e os não privilegiados, para usar um eufemismo." 


\begin{tabular}{|l|l|l|l|l|l|l|}
\hline InterteXto & Uberaba & UFTM & v. 4 & p. 13-34 & 2011 - jul. / dez. & ISSN 1981-0601 \\
& & & n. 2 & & & \\
\hline
\end{tabular}

Nesse sentido, podemos indicar, então, que a estética do grotesco dialoga na obra com o discurso da norma oficial, que não permite algumas expressões que ocupam o baixo, o escatológico, os xingamentos etc., o que, ainda para essa autora, significa uma

"profunda capacidade de mobilizar a linguagem para, por meio dela, refratar a realidade brasileira no que ela tem de mais cruel, de mais violento, de mais desumano e, paradoxalmente, de mais atual. Sem que se possa estabelecer limites claros entre a linguagem e a realidade que ela surpreende e enfoca, o que vai se configurando é a articulação estilisticamente sofisticada entre a degradação social e o tumulto das vozes que constituem o universo urbano" (BRAIT, 2001, p. 246).

Mais um exemplo desse estilo é o que encontramos em Subúrbio:

"A dor. De repente a dor. De dentro pra fora. Um peso. Envolveu o velho num abraço de ferro. Não podendo correr, andou arrastando os calcanhares. Tensionando tudo acima dos joelhos. Sempre assim: primeiro um certo mal-estar, a pressão na barriga, as correntes de músculos apertando o seu torniquete, cercando a partir das costelas, depois descendo. $O$ caminho se enrijecendo desde o diafragma até as nádegas trêmulas. A coluna envergada. $O$ peso. A evolução dos intestinos. Abriu a porta do banheiro com os ombros. As mãos amparando a cintura paralítica. Virado pela dor, pela tensão do corpo transformando-se num balão de gás e fezes. Ele se precipitou no banheiro, caindo sobre a privada segundos antes de a força autônoma das vísceras abrir a flor do seu cu e fazêla jogar a mesma eterna água turva que as suas tripas conseguiam produzir. (BONASSI, 2006, p. 75)

Um dos recursos mais marcantes em Subúrbio é o emprego de um estilo marcado pela desobediência à norma linguística canônica da língua nas ações das personagens chegando mesmo ao nível do escatológico, o que, então, nos permite falar no emprego de um estilo impregnado pelas formas do grotesco. Dessa maneira, podemos afirmar de início que no narrador de Subúrbio encontramos as vozes do estilo grotesco dialogando com as vozes consideradas oficiais da Literatura, uma vez que o leitor é pego de surpresa quando se depara com algumas passagens escatológicas do livro, pois temos 


\begin{tabular}{|l|l|l|l|l|l|l|}
\hline InterteXto & Uberaba & UFTM & v. 4 & p. 13-34 & 2011 - jul. / dez. & ISSN 1981-0601 \\
& & & n. 2 & & & \\
\hline
\end{tabular}

como pressuposta a concepção de que, em se tratando de texto literário, a linguagem costumeiramente empregada é a que se pauta nos modelos tradição culta. No entanto, como veremos, esta "transgressão" do estilo culto não é nada gratuito, afinal esta é a forma encontrada pelo autor para aproximar mais toda a trama à realidade dos fatos que realmente ocorrem no nosso meio e que sabemos bem registrados com linguagens muito variadas e nem sempre cultas, isto porque o dialogismo bakhtiniano a que nos referimos é "um fenômeno que se articula a partir da representação da voz não apenas dos personagens, mas de estilos, de épocas, de grupos sociais." (MACHADO, 1995, p. 62)

Durante a leitura de Subúrbio, o leitor notará que, ao lado do grotesco, temos também a voz de um estilo oposto: do poético, principalmente quando o narrador se refere à relação do velho com a menina pela qual fica obcecado, como vemos nos trechos abaixo:

"Enquanto ela caminhava - e caminhava na direção dele! - ele percebia que o que ela fazia mesmo era tirar a chuva, a umidade, de dentro dele próprio. Isso de tal jeito que quando ela sorriu pra ele, ele tinha se esquecido - não tinha se esquecido de uma coisa que pudesse lembrar, mas tinha encontrado o esquecimento e assim, esquecido todo o resto" (BONASSI, 2006, p. 143) (grifos nossos);

"Teve vergonha de ficar olhando muito tempo. Em seguida, como se a sua boca ganhasse um reforço de vida e falasse por todo o seu corpo, disse assim, ainda com a cabeça baixa, mas sem olhar praquele pé encardido" (BONASSI, 2006, p. 146) (grifos nossos);

"Na escola só a luz acesa no quarto e cozinha dos fundos, onde morava a família do zelador. Ficou esperando que pelo menos o vulto do homem aparecesse no vidro canelado. Não. Notou um cheiro de banho, só isso. Um cheiro de banho (...) Aquela escola vazia de crianças dava um medo triste no velho. Voltou a andar. Na sala de um sobrado a luz iluminava com fantasmas azuis o rosto de um casal. (...) Tornou a voltar-se, continuou subindo. $O$ velho percebia um vento que ia e vinha e, com ele um ruído de mar quebrando dentro da sua orelha" (BONASSI, 2006, p. 151) (grifos nossos); 


\begin{tabular}{|l|l|l|l|l|l|l|}
\hline InterteXto & Uberaba & UFTM & v. 4 & p. 13-34 & 2011 - jul. / dez. & ISSN 1981-0601 \\
& & & n. 2 & & & \\
\hline
\end{tabular}

"Pensou na menina com a vitalidade do temporal: levando palitinhos no meio-feio, rolando pedrinhas, aguando plantas, conduzindo barquinhos de papel, empurrando casas de cima de morros, jogando morros por cima de casas... Embalado pela força irrigadora dessa memória, um arrepio profundo de felicidade abriu uma comporta dento dele logo que a menina apareceu por trás de uma coluna de cimento" (BONASSI, 2006, p. 196) (grifos nossos);

"A manhã passava com o silêncio que podia, mas por baixo do barulho das coisas que aconteciam de dia deu pro velho ouvir de longe quando a menina desceu a rua correndo e chorando. Um choro que transbordava por cima do passarinho na palma da sua mão" (BONASSI, 2006, p. 230) (grifos nossos).

Esses trechos revelam uma forma poética de lidar com alguns fatos de modo muito contrastante com outras na mesma história, perpassadas pelo estilo grotesco. Essa mistura de estilos, ou se preferirmos, esse diálogo entre essas formas estilísticas dão uma dinâmica toda especial à obra. Isso diz respeito ao sentido que a vida ganhou depois de o velho se apaixonar pela menina.

No entanto, esse poético manifesta-se por intermédio de registro característico da oralidade, necessário para a trama do livro se aproximar do real. Exemplos desse registro são, entre outros, a abreviação da preposição "para" em "pra", a aglutinação da preposição "para" e do pronome "aquele" em "praquele", o próprio tom de informalidade na narração. Entre o poético oralizado e o grotesco, encontramos ainda o discurso da inocência, da pureza das crianças, como no trecho abaixo:

"Os dias: - Dizem que quando a gente come mexerica e engole o caroço, o caroço cresce na barriga, vira árvore e tudo por dentro da gente. É verdade? - Não, não é verdade. Em volta do caroço que você engole, dentro da sua barriguinha, vai formando um pedacinho de cocô. O caroço fica lá, anda por todo o seu intestino no meio daquele pedacinho de cocô, até que sai. Quando o cocô vai embora, vai pro cano e depois pro rio e depois pro mar. Esse seu cocô com o carocinho no meio 


\begin{tabular}{|l|l|l|l|l|l|l|}
\hline InterteXto & Uberaba & UFTM & v. 4 & p. 13-34 & 2011 - jul. / dez. & ISSN 1981-0601 \\
& & & n. 2 & & & \\
\hline
\end{tabular}

vai virar é uma árvore no fundo do mar... E olha, mesmo lá, essa mexerica de mar que nos peixes do fundo vão comer, ela mesma, ainda vai ser docinha!" (BONASSI, 2006, p. 210)

As vozes que anunciam os estilos presentes no livro, em alguns momentos, são bastante contrastantes. Se num momento como esse, a inocência está presente na trama, em outro, o erotismo é marcante:

"Então, com muito cuidado, tirou a lona das mãos da menina. Vendo que os cabelos dela já estavam empoeirados, pegou o lenço, segurou a cabeça da menina pelo queixo e foi passando o pano xadrez, tirando o pó e ao mesmo tempo alisando. Em poucos instantes 0 velho notou que aquela cabecinha comprimida no seu ventre transmitia um aconchego que percorreu as suas virilhas, dando uma volta pelas coxas e terminando no último guizo da espinha" (BONASSI, 2006, p. 206);

"O lugar onde eles estavam nunca mais vão conseguir lembrar. Estavam só ocupados de si. A menina, sentada numa posição inferior em relação ao velho, oferecia por isso a ele: curvas abertas do seu pescoço, as omoplatas forçando o tecido de algodão da camiseta e as ondulações de cada vértebra descendo pra cinturinha. Tudo isso o velho tinha de onde ele estava. Tinha também a penugem recobrindo toda a pele, fio de seda germinando de cada poro. Mas isso foi depois. Depois de olhar bem. De repente. Foi o dedinho da menina que surgiu no pulso do velho." (BONASSI, 2006, p. 242)

Descrições de momentos grotescos, erotismo, poesia - ao tratar de aspectos mais sublimes - dão cor e vibração à história narrada em Subúrbio. Além dessas vozes que se podem ouvir no livro, ainda notamos algumas outras, que servem para situar ainda mais a trama no contexto criado pelo autor, ou seja, o lado nada característico pelo ritmo de vida comedido, pautado pelas regras da "boa" etiqueta cultivada por grupos sociais privilegiados. 0 escancaro, a linguagem livre de qualquer regulação de vocabulário, enfim, a linguagem mais chula, porém, a que se aproxima mais da realidade, é constante. O momento em que o narrador expõe os pensamentos do velho a respeito do vizinho doente: o marido da mulher vizinha que ele havia espionado por um buraco na parede quando ela estava no banheiro em sua intimidade. 


\begin{tabular}{|l|l|l|l|l|l|l|}
\hline InterteXto & Uberaba & UFTM & v. 4 & p. 13-34 & 2011 - jul. / dez. & ISSN 1981-0601 \\
& & & n. 2 & & & \\
\hline
\end{tabular}

Flagram-se também aqui elementos do grotesco:

"O vizinho. A história do vizinho que o velho guardava na cabeça era mais uma história de doença. Doenças eram tão comuns naquele lugar que o velho tinha o critério de lembrar pelas doenças que tinham atingido as pessoas da sua memória. (...) Depois, depois que ele passou por três operações, foi aposentado. Ainda depois foi enterrado com uma bandeira em cima do caixão, talvez de São Paulo. Pode ser que não. Mas isso foi depois. Antes o velho lembrava das três operações: na primeira, tiraram todo o intestino e lavaram numa bacia; na segunda tiraram um pedaço desse intestino; na terceira tiraram um pedaço de víscera tão grande que o corpo dele ia ter que reaprender a se virar com o resto. Tudo muito devagar. Tão devagar que resolveram abrir um novo buraco do lado esquerdo, onde as fezes iam caindo numa bolsa plástica." (BONASSI, 2006, p. 101)

Ainda em relação às vozes que se opõem na obra, encontramos passagens que marcam o religioso em meio ao discurso erótico e grotesco, e ainda, como já dissemos anteriormente, o discurso das simpatias, das conhecidas correntes milagrosas como nos exemplos abaixo:

"Pôs a caixa na cova, então lembrou que era bom ter um missal ali. Como não o tinha, leu o 'Oferecimento do Sacrifício Perpétuo da Santa Missa' que tinha dentro da carteira desde moço: - 'Santíssima Trindade, uno-me a todos os sacerdotes que celebram o Santo Sacrifício nestas 24 horas, e além dos fins pelos quais foi instituído de adoração, de agradecimento, de impetração e de apropriação, vos peço por cada missa: Primeiro: a libertação de uma alma do purgatório. Segundo: a verdadeira dor dos meus pecados. Terceiro: a conversão de um membro de cada seita fora da verdadeira igreja. Quarto: a conversão de um pecador" (BONASSI, 2006, p. 232);

"Envelope sem remetente. No nome da velha. Ela procurou pelo carimbo. Era do Correio Central. Depois abriu e encontrou a folha. Xerox: 'Beije alguém que você ama muito quando receber esta carta. Ainda mais porque ela veio trazer-lhe muita sorte. A cópia original está na Inglaterra. Ela roda o mundo em nove meses. A sorte foi enviada a você. Você terá sorte nos 


\begin{tabular}{|l|l|l|l|l|l|l|}
\hline InterteXto & Uberaba & UFTM & v. 4 & p. 13-34 & 2011 - jul. / dez. & ISSN 1981-0601 \\
& & & n. 2 & & & \\
\hline
\end{tabular}

próximos dias. Leia com atenção. Isto não é brincadeira (...) Envie 20 (vinte) cópias desta carta. Observe o que vai acontecer em 4 (quatro dias)." (BONASSI, 2006, p. 209)

Não há dúvida de que todo esse contraste de vozes pertencentes a contextos diferentes fazem de Subúrbio um texto rico, tão rico quanto o contexto das realidades populares de algumas áreas em que a diversidade é marca registrada. Inclua-se ainda a todo esse contexto, o conhecido discurso do jogo do bicho:

"E começou a falar tudo o que sabia. As palavras numa rajada: - ... 01-02-03-04 por exemplo é avestruz, 05-06-0708 já é água, 09-10-11-12 burro, 13-14-15-16 borboleta, 17-18-19-20 é o cachorro, a cabra é 21-22-23-24-25-26-27-28 o carneiro, 2930-31 ou 32 é camelo." (BONASSI, 2006, p. 73)

\section{Considerações finais}

É evidente que o leitor deste trabalho, após a leitura na íntegra e mais atenta da obra Subúrbio, de Fernando Bonassi, poderá perceber exatamente o que quisemos mostrar aqui, ou seja, a rede de vozes que nos conduzem a variados discursos e estilos que perpassam a trama. O que fizemos aqui foi apenas uma amostra parcial do todo da obra. Destacamos que o importante é que passemos a apreciar as produções literárias com olhos mais sensíveis, a fim de entendermos que a beleza de uma narrativa não está apenas nas que são registradas com a linguagem culta adotada pela tradição literária, pela pena de grandes e fabulosos autores que nos propõem momentos de grande prazer com a riqueza de seus estilos. Temos de considerar também a beleza do estilo, digamos, marginal, aquele cujo autor delega a seus narradores estilos considerados por muitos como menor, chulo pelo vocabulário, construções lingüísticas e cenas empregadas, afinal se entendermos que a Literatura está também ao nosso serviço para nos levar a refletir acerca da vida em todas as esferas, por que não empregar suas linguagens correspondentes?

Em Subúrbio, Bonassi faz emergir situações muito comuns do nosso cotidiano 


\begin{tabular}{|l|l|l|l|l|l|l|}
\hline InterteXto & Uberaba & UFTM & v. 4 & p. 13-34 & 2011 - jul. / dez. & ISSN 1981-0601 \\
& & & n. 2 & & & \\
\hline
\end{tabular}

com o cuidado de fazer com essas situações sejam muito verossímeis, isso porque soube muito bem estabelecer um diálogo entre estilos que, em alguns momentos, são bastante contrastantes. O emprego do grotesco, que não é gratuito e que possui a função de destacar o contexto em que se passa a trama, juntamente com momentos de poesia, erotismo, inocência, religiosidade, crise conjugal, entre outros, faz com que a obra não seja monótona, efeito que não teria sido atingido, se ao narrador fosse permitida apenas um único tom que, de certa forma, nivelasse a linguagem de toda a trama num único patamar estilístico.

\section{Referências}

BAKHTIN, Mikahil. Marxismo e Filosofia da Linguagem. São Paulo, Hucitec, 1999. Problemas da Poética de Dostoievski. Rio de Janeiro: Forense Universitária, 1997.

BONASSI, Fernando. Subúrbio. Rio de Janeiro, Objetiva, 2006.

BRAIT, Beth. "Espaço urbano brasileiro, violência e linguagem". In: Dino Preti e seus Temas: Oralidade, Literatura, Mídia e Ensino. São Paulo, Cortez, 2001.

BRAIT, Beth \& MELO, Rosineide de. "Enunciado / Enunciado Concreto / Enunciação" In: BRAIT, Brait (org.). Bakhtin. Conceitos-Chave. São Paulo, Contexto, 2005.

MACHADO, Irene. O Romance e a Voz: A Prosaica Dialógica de M. Bakhtin. Rio de Janeiro, Imago, 1995.

PINTO, Manuel da Costa. "Apresentação". In: BONASSI, Fernando. Subúrbio. Rio de Janeiro, Objetiva, 2006, p. 02-06.

SODRÉ, Muniz \& PAIVA, Raquel. O Império do Grotesco. Rio de Janeiro, Mauad, 2002.

STAM, Robert. Bakhtin: da Teoria Literária à Cultura de Massa. São Paulo, Ática, 1992. 